\title{
The Role OF StUdent-RUN JouRnals in OpENING North AMERICAN LAW
}

\author{
FRANCES OLSEN ${ }^{*}$
}

After listening to some of my colleagues here today, I realize that my presentation is quite in support of student-run law reviews. I should perhaps even call it "a panegyric on the student-run law review."

The student-run law review is an institution little known outside of North America. One could say with some justification that the institution began almost by accident. It has persisted largely unchallenged. Why has there been so little serious or significant questioning of the student-run journals?

A large number of law professors served on student-run journals, and for many, if not most of them, doing so was a positive, in some cases formative, experience. Thus the same people who would be the most likely or in the best position to bring about a change are emotionally unlikely to want to disrupt or damage the institution of the student-run law review.

On the other hand, some of these nostalgically supportive professors become quite annoyed when the journals reject an article by them or edit it in a manner not to their liking. Some grudging or hidebound professors even become annoyed when the journals accept articles they themselves dislike or articles written by perceived opponents or enemies. Many middle-aged or older professors romanticize their own law review experiences and may grouch that "standards have fallen."

Thus the institution of the student-run law review is strong and largely unchallenged. Yet, it is also frequently criticized, as it has been at this symposium today. Actually, I do not strongly disagree with many or most of the criticisms recited this afternoon. Rather, I would maintain that similar or more significant criticisms would apply to any other system that we might adopt for producing legal periodicals, and I consider the criticisms of student-run law journals greatly outweighed by the advantages.

As critics charge, much of what student-run journals publish is conventional, irrelevant, and over-footnoted. "Rank beginners" are solely responsible for what is printed, generally without peer review of any kind. The closest approximation of peer review is the somewhat random practice of student editors seeking advice from their friendly professors.' Traditions of seeking such advice vary from school to school and from one set of editors to another. At best, the practice is haphazard. At worst, it can lead to systematically poor advice. The professors giving advice are chosen more randomly than through actual peer-review processes, and they are not accountable in the same way for the opinions they give. I would worry that some small-minded professors might through casual, disparaging comments or dismissive assertions discourage the publication of a meritorious article whose thesis or author they opposed. These same professors, if they were called upon to write a more formal peer review, might be unable to

Professor of Law, University of California at Los Angeles.

In a speech at the Indiana Law Journal banquet, Professor Ronold D. Rotunda advised the student editors to seek the advice of their professors regarding which articles and student notes to publish, assuring them that they could seek advice without jeopardizing their own valued independence. See R.D. Rotunda, "Law Reviews-The Extreme Centrist Position" (1986) 62 Ind. L.J. 1 at 9. 
justify their negative evaluation or be less inclined to jeopardize their own reputations with the editors of peer-reviewed journals by manufacturing unworthy criticisms.

As critics charge, aggressive rewriting of manuscripts does take place. I remember during my own first year on law review, I assisted the editor-in-chief to essentially destroy what had been a hard hitting controversial challenge to more conservative views of criminal procedure. The prior board of editors accepted the article, and my own editor-in-chief would not have accepted it. He did his best to make it "responsible." I found myself in the role of a token liberal fighting to keep some modicum of the original spirit in the article. In the years since then, the field of criminal procedure has become even more conservative; the article even as edited would perhaps now seem hard hitting and controversial. But at the time, the author rightly felt disappointed in the deradicalization that had taken place.

As critics charge, law review editors do sometimes unconscionably bully pre-tenure professors. They also do sometimes publish the work of popular professors up for tenure without sufficient regard to the quality of the work they are publishing. And if these professors are also popular with the faculty, or even if they are simply sufficiently "one of the guys," the faculty may grant tenure on the basis of one or two articles in their own law review, even when publication in their own law review is about the only thing that can be said for the article or for the professor. Faculty-edited reviews are subject to the same kind of bias, and indeed it is even more likely to be the same people who are benefited by generous tenure decisions who would benefit from generous publication decisions in a faculty-edited review.

Finally, as critics charge, student-run law reviews are to some extent reproducers and supporters of hierarchy. As much as professors, students try to help a school claw its way up the law school hierarchy by their fingernails. ${ }^{2}$ This sometimes does lead to accepting articles by well-known authors and rejecting those by unknown people. ${ }^{3}$ It may lead to a refusal to take chances on controversial articles and to the worst kinds of conformity. ${ }^{4}$ Yet, none of the critics of student-run law reviews have suggested or even hinted at any convincing alternative system that would avoid the problem of journals seeking hierarchical success in such conventional terms. Most of the alternatives proposed by critics would, in my view, be much more rather than less likely to reproduce and support hierarchy within the legal profession. Indeed, there is additional danger that journals might depend upon commercial or right-wing foundation support, compromising academic independence and integrity in ways the student journals never even approach.

Many of the perceived or claimed "weaknesses" of student-run law journals are also strengths. Beginners choose the articles, and they are often open to new ideas and fresh approaches. Although there may be some truth in Allen Hutchinson's claim that creative work is kept at the margins, the more important point is that such work is nevertheless published and one can find and read it. Those interested in creative work learn to find and read the margins. At least the margins are there. There are a great number of law reviews, which means that things can get published in law.

2 $\quad$ See generally P. Nichols, "A Student Defense of Student Edited Journals: In Response to Professor Roger Cramton" (1987) Duke L.J. 1122 at 1125 (student editors are achievement oriented and "identify themselves closely with their law reviews").

3 Compare R.M. Blank, "The Effects of Double-Blind Versus Single-Blind Reviewing: Experimental Evidence from The American Economic Review" (1991) 81 Am. Econ. Rev. 1041 at 1063-64 (suggesting limited effect of identity of author in publication decisions of The American Economic Review).

+ Contra Nichols, supra note 2 at 1125-26 ("Law reviews succeed by being innovative and interesting, not by hanging back and letting others take the lead"). 
In other academic disciplines, disciplines that do not have student-run journals, there are whole new fields and approaches that can be suppressed and overlooked for years. It can take years for a new approach to be accepted by any single professional journal. There is probably worthwhile scholarly work in some of these academic disciplines that has never seen the light of day. In these academic fields, where journals are professional or peer reviewed, new areas of inquiry can be effectively blocked by those entrenched in editorial positions. In contrast, I am not aware of any good law review article that has not been able to find a publisher. While the student-run journals are sometimes similarly reluctant to pick up new approaches, they are much less so, and their personnel change every year, making the entrenched quality of conservativism much less troubling.

At this point, I am often accused of being spoiled and not knowing what I am talking about. As many people know, I had the good luck to have my first article published in the Harvard Law Review. This article was featured in the latest study of the "top 100" most-cited law review articles. ${ }^{6}$ Thus, some claim that of course I have no trouble publishing anything I write and that I am out of touch with the real world of struggling new authors. In fact, that first article I wrote was rejected by some ten other law journals, giving me at least some taste of the real world. Moreover, I have been making the claim for some fifteen to twenty years that any good law review article, however unconventional, can get published. In every case in which a struggling new author has taken me up on it, I have been able to get his or her article published. The first example I can remember is an article by Ellen M. Kelman published in the law review of Saint John's Law School. ${ }^{7}$ The most recent example is a piece by an anonymous author, apparently from the University of Texas Law School, who interacted with me through an intermediary and whose identity I still do not know. ${ }^{8}$ In these cases, the authors and the journals in which they published represented themselves as being equally happy and appreciative. The Kelman article is among the more frequently cited in the Saint John's Law Review, and the Anonymous piece nicely complimented a symposium the U.C.L.A. Women's Law Journal published in the following issue."

Several new fields in legal scholarship - critical legal studies, feminist legal theory, critical race theory, and queer theory, to name a few - would not, in my view, have been nearly as easy to get going had it not been for the institution of the student-run law journal. Legal historians, if they look into the question, might discover that this is in no way a new phenomenon..$^{10}$ It may well be that legal realism, for example, was able to proceed as it did because of the institution of student-run journals."

F. Olsen, "The Family and the Market: A Study of Ideology and Legal Reform" (1983) 96 Harv. L. Rev. 1497.

" F.R. Shapiro, "The Most-Cited Law Review Articles Revisited" (1996) 71 Chi.-Kent L. Rev. 751 at 757, 771, 773.

7 E.M. Kelman, “American Labor Law and Legal Formalism: How 'Legal Logic' Shaped and Vitiated the Rights of American Workers" (1982) 58 St. John's L. Rev. I.

* Anonymous, "Barbeque of the Vanities" (1999) 10 U.C.L.A. Women's L.J. 1.

" Symposium: "Textbook Sexism: Discrimination Against Women in Academia" (2000) 10 U.C.L.A. Women's L.J. 235.

11 Curiously, some of the critics of student-run law reviews seem to write as though the institution did not exist until the late 1960s or 1970s. Compare, e.g., R. Posner, "The Future of the Student-Edited Law Review" (1995) 47 Stan. L. Rev. 1131 at 1132-33 (claiming a "Golden age" of student-edited law review drew to a close between 1970 and 1990).

1I I am unaware of any study that would substantiate or undermine this assertion. I hope that some ambitious law student or legal historian will examine the relationship between student-run law reviews and the publication of legal realist writing. 
Critical legal studies benefited from the law school hierarchy in a particular way. One of the first critical legal studies articles was "Form and Substance in Private Law Adjudication" by Duncan Kennedy, which was published in the law review at Harvard University, where Kennedy was teaching and still teaches. ${ }^{12}$ Because the Harvard Law Review published Kennedy's article, other journals felt justified in publishing critical legal studies articles. As early as 1984, the Stanford Law Review decided to do a symposium on critical legal studies. ${ }^{13}$

Similarly, while a smattering of feminist legal theory articles were published before 1983 , the publication of my article, "The Family and the Market," at Harvard bolstered by Yale Law Journal's publication of Ann Freeman's feminist critique of Supreme Court decisions ${ }^{14}$ opened the floodgates for hierarchically ambitious law reviews to publish feminist articles. ${ }^{\text {is }}$

In other academic disciplines, many of these new fields would not be published without a long and arduous struggle. In the United States and Canada, the situation is different in law. Lots and lots of stuff is published, and much of it is not read. It is up to the readers and to those who cite it to make law review scholarship known. ${ }^{16}$

D. Kennedy, "Form and Substance in Private Law Adjudication" (1976) 89 Harv. L. Rev. 1685. This has been a stunningly successful article. As of the last study I know of on the topic of citation, the article was the tenth most frequently cited article of all time and the only article in the top fifteen published so recently (1976) and thus accumulating citations so quickly. See Shapiro, supra note 6. Oddly, a student defender of student-run law reviews cites the review volume that published this symposium to support Ronold D. Rotunda's claim that law reviews might be captured by one group and become ideologically skewed. Nichols, supra note 2 at 1127 , citing Rotunda, supra note 1 at 9 . Nichols characterized the claim as "if a group such as Critical Legal Studies edited [a faculty-edited] review, much legal scholarship would be excluded." He says, "[t]he thirty-sixth volume of the Stanford Law Review illustrated Professor Rotunda's point nicely. The first two-thirds of the volume contains only CLS related pieces." He fails to mention or perhaps did not even notice that the CLS related pieces were part of a symposium on the topic of CLS scholarship. The Stanford symposium included several articles sharply critical or even dismissive of CLS, see particularly P.E. Johnson, "Do You Sincerely Want To Be Radical?" (1984) 36 Stan. L. Rev. 247; L.B. Schwartz, "With Gun and Camera Through Darkest CLS-Land" (1984) 36 Stan. L. Rev. 413. The symposium was not twothirds of the volume but took up 674 pages, just over one-third of the 1533-page volume. The rest of the claimed two-thirds is filled with non-CLS articles, such as Thomas Jackson on Bankruptcy, 36 Stan. L. Rev. 725 and Roberta Romano on Corporate Law Reform, 36 Stan. L. Rev. 923. Rotunda's point was more hostile to CLS than represented by the student editor. Rotunda asserted that if it "captured" a law review, the CLS movement would "impose its views as to what constitutes correct legal scholarship": Rotunda, supra note 1 at 9 . Given the symposium's appalling lack of racial diversity and the symposium editors' refusal to include any scholarship by women, it would hardly be viewed as "correct" as Rotunda seems to use the term.

is A.E. Freedman, "Sex Equality. Sex Differences, and the Supreme Court" (1983) 92 Yale L.J. 913. For one of the earliest claims that law reviews "have all been sucked into a polite little game of follow-the-leader with the Harvard Law Review setting the pace" see F. Rodell, "Goodbye to Law Reviews" (1936) 23 Va. L. Rev. 38 at 44.

For a number of years Mary Joc Frug and I maintained a "Bibliography of Feminist Legal Theory." In the late 1980 s it began to be increasingly difficult to keep it up as the number of published articles ballooned.

16 The Internet and the opportunity it offers for electronic publication may turn out to make it easier to publish in disciplines outside law. In a sense, the Internet is like an extreme exaggeration of the student-run journal. Anyone can post anything, and perhaps no one will read it. Or perhaps it will take off and become a success. 
Perhaps reasons like these are behind some of the criticism of student-run journals that have been coming from the right wing in the United States. ${ }^{17}$ While one might think that someone like Richard Posner would appreciate the market-like approach of the student-run law journal system, ${ }^{18}$ most of the right wing seems to take the other side of the debate.

There are disadvantages to the North American approach of letting a thousand flowers bloom ${ }^{19}$ and a thousand articles a month be published. ${ }^{20}$ There is a lot of stuff published that most people simply do not read. Some authors joke that they think more law review editors read their article in the editing process than ever read it after it was published. ${ }^{21}$ There is a significant number of articles that have never been cited. $^{22}$

A further disadvantage is that the good material that has been published is scattered among a great many journals, and it can be quite expensive for law libraries to subscribe to all the journals that at one time or another publish important articles. It is virtually impossible for financially strapped schools to have a sufficient periodical collection in their law library. Most overseas schools carry only a small fraction of the United States and Canadian journals. The only solution I know to this problem is a partial one. The Dartmouth Press, a well-known international publisher, has instituted a series designed to make English-language law journal scholarship more available. ${ }^{23}$ There are at present some sixty volumes in the series, including fields ranging from Critical Legal Studies to Antitrust Law. The articles are reproduced in their entirety with a double-pagination system, which facilitates citation, but the series itself is quite expensive. ${ }^{24} \mathrm{I}$ put together a two-volume set on feminist legal theory, which Dartmouth issued in paperback as well as in hardcover ${ }^{25}$ Even the paperback set, however, is expensive. ${ }^{26}$ In England, Cambridge University Law Library has only the paperback version of Feminist Legal Theory.

Finally, I consider the student-run law review to be an excellent institution for legal education. One of the proper roles of professor authors, in my view, is to fight it out with the

Some might find the proposal Posner, supra note 10, makes to be revealing in this regard. He urges student-edited law reviews to focus on doctrinal scholarship and to leave the choice to publish or refuse to publish non-doctrinal articles - in which he includes feminist jurisprudence, critical race theory, and "gay and lesbian legal studies," (ibid. at 1133) - to faculty-edited journals (ibid. at 1136).

Ix See Posner, supra note 10 at 1135 (asserting, without explanation, an "absence of the spur of competition" in law reviews). Contra, ibid. at 1136 (referring to the "competitive advantage" speed of publication gives student-edited law reviews over peer-reviewed journals).

See M. Tse-Tung, "Let a Thousand Flowers Bloom" (speech in Beijing, China on 27 February 1957) cited in T. Augarde ed., The Oxford Dictionary of Modern Quotations (New York: Oxford University Press, 1991) at 146.

21 The estimate of just over 1,000 articles per month was derived by Kevin Gerson of the U.C.L.A. Law Library through an analysis of the Index to Legal Periodicals. See e-mail from Kevin Gerson to Author, 7 August 2001.

21 Compare Rodell, supra note 14 at 41 (referring to "all three" of the readers of a hypothetical law review article and arguing that "[a] man [sic]who writes a law review article should be able to attract for it a slightly larger audience than a few of his colleagues who skim through it out of courtesy and a few of his students who sweat through it because he has assigned it").

22 There are many such articles, but if I were to cite them, they would no longer be un-cited, so I shall not do so. The skeptical reader might check for himself or herself.

$33 \quad$ This series was the co-operative effort of Dartmouth and N.Y.U. Press. See catalogues of either press.

24 At the present time, the cost is $\$ 9,540$ (US) for the whole set, with individual titles in the set ranging from $\$ 125$ to $\$ 250$.

25 As far as I know, the only other volume in this series issued in paperback as well as hardcover was the single volume on Critical Legal Studies (James Boyle, ed.).

26 The regular price for the two volumes is $\$ 59$ (US). 
law review editors and to educate them in the process of publishing one's article. Much education takes place between the editors as well. A good law review provides a vibrant academic atmosphere and the opportunity for a lively community of young scholars to develop. This is one reason why having served on law review is considered such a plus for those entering law school teaching.

The student-run law review provides a centre for students to accept responsibility for their own education. Instead of presenting yourself to the law school - here I am, educate me the student views the law school as a resource to be made use of for the benefit of his or her education. In my view, all students should have some centre outside of law school classes in order to take control over and responsibility for their own education. There are many possible centres, such as public interest law firms, legal aid offices, moot court, and some student organizations. The law review is one of many such centres. For many people it is a particularly productive centre.

In conclusion, while there are some reasonable criticisms of student-run law journals, many of the criticisms are unreasonable or irrelevant. Moreover, there are many advantages to the current system of student-edited journals. In fact, it may well be the advantages of the studentrun law journals that lie behind some of the criticisms. I note that Richard Posner is quite willing for student-run law reviews to publish conventional, doctrinal articles, if only they would refrain from publishing exactly the kinds of articles that in my view it is so important to have published. ${ }^{27}$ Although "law and economics" presumably would also fall outside the "doctrinal" category and thus be subject to the same presumption against publication in student-edited journals, the Journal of Legal Studies will publish any law and economics articles Posner wishes to have published. More such journals could easily be established and financed by right-wing interests if the Journal of Legal Studies found itself unable to accommodate all the articles it wished to see published.

The most famous criticism of law reviews, Fred Rodell's article "Goodbye to Law Reviews," ${ }^{28}$ is misunderstood when it is used as a critique of the tradition of students editing law reviews. Rodell worried that lawyers were too concerned with serving themselves and insufficiently concerned with serving society. ${ }^{29}$ He hoped that legal writers would change this, ${ }^{30}$ but instead they seemed to be "diddling while Rome burn[s]." ${ }^{11}$ Writing in 1936, Rodell viewed law as "the only alternative to force" for "solving the myriad problems of the world" and wanted legal writers to "be more pointedly aware of those problems" and "recognize that the use of law to help toward their solution is the only excuse for the law's existence, instead of blithely continuing to make mountain after mountain out of tiresome technical molehills." ${ }^{32}$ Too much of the modern criticism of student-edited law reviews is exactly the opposite of Rodell's. Rodell hoped that "[m]aybe one of these days the law reviews, or some of them, will have the nerve to shoot for higher stakes." 33 I believe some of them, at least to some extent, have and that this encourages all of the law reviews to consider doing so.

Ibid. ("II]f any among the lawyers might reasonably be expected to carry a torch or shoot a flashlight in the right direction, it is the lawyers who write about the law.")

lbid. at 43.

lbid.

Ibid. 